\title{
Uncovering Differentially Methylated Regions (DMRs) in a Salt-Tolerant Rice Variety under Stress: One Step towards New Regulatory Regions for Enhanced Salt Tolerance
}

\author{
Liliana J. Ferreira ${ }^{1}$, Mark T. A. Donoghue ${ }^{2,+}{ }^{,}$Pedro Barros ${ }^{1}$, Nelson J. Saibo ${ }^{1}$, \\ Ana Paula Santos 1,*(D) and M. Margarida Oliveira 1,3 \\ 1 Instituto de Tecnologia Química e Biológica António Xavier, Universidade Nova de Lisboa, \\ Genomics of Plant Stress. Av. da República, 2780-157 Oeiras, Portugal; lferreira@itqb.unl.pt (L.J.F.); \\ pbarros@itqb.unl.pt (P.B.); saibo@itqb.unl.pt (N.J.S.); mmolive@itqb.unl.pt (M.M.O) \\ 2 Cold Spring Harbor Laboratory, Cold Spring Harbor, NY 11724, USA; mdonoghu@cshl.edu \\ 3 IBET, Apartado 12, 2781-901 Oeiras, Portugal \\ * Correspondence: apsantos@itqb.unl.pt; Tel.: +351-214469660 \\ + Current address: Memorial Sloan Kettering Cancer Center, 1275 York Avenue, NY 10065, USA
}

Received: 5 November 2018; Accepted: 15 January 2019; Published: 18 January 2019

check for updates

\begin{abstract}
Chromatin structure, DNA methylation, and histone modifications act in a concerted manner to influence gene expression and therefore plant phenotypes. Environmental stresses are often associated with extensive chromatin rearrangements and modifications of epigenetic levels and patterns. Stress-tolerant plants can be a good tool to unveil potential connections between specific epigenetic modifications and stress tolerance capacity. We analyzed genome wide DNA methylation of a salt-tolerant rice variety under salinity and identified a set of differentially methylated regions (DMRs) between control and stress samples using high-throughput sequencing of DNA immunoprecipitated with the 5-methylcytosine antibody (MeDIP-Seq). The examination of DNA methylation pattern at DMRs regions revealed a general tendency for demethylation events in stress samples as compared to control. In addition, DMRs appear to influence the expression of genes located in their vicinity. We hypothesize that short regions as DMRs can shape the chromatin landscape of specific genomic regions and, therefore, may modulate the function of several genes. In this sense, the identification of DMRs represents one step towards to uncover new players in the regulation of stress-responsive genes and new target genes with potential application in enhancement of plant salinity-tolerance.
\end{abstract}

Keywords: differentially methylated regions (DMRs); MeDIP-Seq; rice; salt stress tolerance

\section{Introduction}

Rice is well known for its extreme sensitivity to salinity which may lead to reduced levels of productivity and negative impacts on growth rates, tillering and seed production [1-3]. Thus, distinct perspectives are needed to enhance knowledge about rice tolerance and adaptation to adverse environmental conditions. Several abiotic stresses have been studied such as suboptimal temperature, water and nutrient availability, light, salinity, and temperature conditions. The enhancement of salt tolerance has been achieved by the production of transgenic plants [4]. For example, in rice the overexpression of specific genes, such as OsSta2-D (Oryza sativa Salt tolerance activation 2-Dominant), generated positive impacts on better rice performance under salt stress [5]. Similarly, the overexpression of dehydrin gene, OsDhn1, led to enhanced performance of rice plants subjected to drought and salt 
since these plants showed a high capacity to minimize the level of reactive oxygen species (ROS) in cells increasing their tolerance to imposed oxidative stress [6]. Other approaches to uncover the molecular mechanisms underlying abiotic stress responses have involved the identification of miRNA profiles [7], for example, in maize, the downregulation of specific miRNA was detected in response to salt stress [8]. Genome wide demethylation and structural chromatin remodeling are also common events resulting from exposure to salt stress [9-13]. In Antirrhinum majus, the exposition to low temperatures induced DNA demethylation of Tam3 sequence which was correlated to its activation [14]. The germination of rice seeds under salt stress conditions also generated a global decrease of DNA methylation [13] and a remarkable decondensation of interphase rDNA chromatin which became more evident at heterochromatic knobs [9]. The genome wide loss of DNA methylation of rice under salinity stress was found particularly evident in leaf tissues as compared to roots [11-13]. DNA methylation levels can be also altered in result of exposure to distinct chemical stresses. For example, toxicological studies in rice involving the application of atrazine (herbicide) revealed the existence of methylation changes at specific genes with a role in atrazine metabolism [15]. The exposure to chemical compounds targeting epigenetic regulators such as 5-azacytidine or trichostatin-A also affected the organization of interphase chromosomes and epigenetic levels in wheat nuclei [16]. Shifts in DNA methylation levels and patterns have been connected with plant capacities for adaptation and tolerance to stress. Rice genotypes with distinct degrees of susceptibility to various stresses possess distinct levels of DNA methylation and different abilities to adjust DNA methylation levels [13,17-20]. For instance, the salinity tolerant rice variety 'Pokkali' showed a higher ability to alter DNA methylation levels than sensitive varieties [13]. A salt-tolerant cultivar of foxtail millet (Setaria italica) under salinity stress also showed a genome wide loss of DNA methylation as compared to a sensitive one [21]. The ability to tolerate stress can also be influenced by genetic stress, namely by genome restructure after merge of distinct genomes in the same nucleus, as it happens in somatic hybridization or polyploidy $[17,22]$, generating unpredictable reorganization of methylation patterns and novel maps of gene interactions [23]. For example, the enhanced salinity tolerance of salinity-tolerant wheat cultivar cv. SR3 was attributed to specific methylation changes arising from somatic hybridization [17]. Similarly, the drought-tolerance of rice line DK151 was attributed to extensive DNA methylation changes as result of the introgression feature of this line [19]. These studies indicated a connection between DNA methylation dynamics and plant capacity to tolerate stress.

The response to challenging situations has also been correlated with the induction of differential methylation regions (DMRs), being the DMRs location determinant in gene regulation $[18,24,25]$. DMRs have been mostly studied in humans and have been denominated according to their role specificity as tissue-specific DMRs (tDMR), cancer-specific DMRs (cDMR), reprogramming-specific DMRs (rDMR), imprinting-specific DMRs (iDMR), and aging-specific DMRs (aDMR) [26-28]. In plants, DMRs have been identified between different tissues along in vitro culture such as in Populus tissue dedifferentiation and regeneration [29]. DMRs were also identified between inbred lines of maize (Zea mays) [30], in soybean (Glycine max) [31], in rice hybrids [32], and also in Arabidopsis after an induced drought simulation [33]. DMRs were also identified between rice lines with contrasting behaviors in response to abiotic stresses. For example, rice drought-tolerant plants showed less drought-induced DMRs than drought-sensitive plants [19] which may suggest, as referred to by Zheng et al. [34], that drought-tolerance maybe associated to a more strength of methylome pattern under stress.

Following our previous studies [13] we have furthered investigated the patterns of DNA methylation in 'Pokkali', a rice variety that simultaneously shows a great capacity to tolerate salinity stress and to rapidly shape DNA methylation levels when exposed to salinity. The methylome of 'Pokkali' was analyzed by methylated DNA immunoprecipitation (MEDIP-Seq) with focus on detection of DMRs upon salt stress exposure versus a control condition. The implementation of strict criteria for bioinformatics analysis led to the identification of 53 DMRs. Some of these regions were analyzed in detail by bisulfite sequencing (BS-Seq) and all identified DMRs revealed, in general, a loss of 
methylation upon salt. Moreover, most DMRs were found nearby specific genes and this may suggest that DMRs can be one more player involved in epigenetic gene regulation.

\section{Results}

\subsection{The 'Pokkali' Methylome and the Identification of DMRs between Salinity and Control}

The two sequencing runs performed generated 13.6 and 17.2 million $50 \mathrm{bp}$ single end raw sequencing reads for salt and control conditions, respectively. After removal of adapter contaminants and low-quality reads, 3.5-4.2 million uniquely mapped high-quality reads were retained for each condition and replicate. The percentage of uniquely mapped reads was considerably higher on the non-immunoprecipitated sample (approximately 50\%) contrasting with approximately $25 \%$ for the immunoprecipitated samples (Table 1). Regarding the genome coverage, approximately $7.5 \%$ of cytosines were covered by at least one uniquely mapped read (Table 1). The methylome of 'Pokkali' consisted on an even distribution of DNA methylation throughout the entire chromosomes, with no obvious enrichment on specific chromosome regions, such as pericentromeric heterochromatin (Figure 1A and Figure S1).

The analysis of differential methylation based on MeDIP-Seq data, using the MEDIPS program, as mentioned in the methods section, enabled the identification of 53 DMRs between control and salt stress samples. The DMRs that were close to each other (less than $500 \mathrm{bp}$ ) were merged originating 22 DMRs (ranging from 100 to $1000 \mathrm{bp}$ ) (Table 2). Regarding the DMRs profile, the methylation variation induced by salinity consisted, in general, of DNA demethylation (Figure 1B and Figure S2). For some DMRs, in control 2, there was also some loss of DNA methylation under stress (Figure S2) but the general tendency was a loss of methylation of DMRs under salinity stress. A detailed analysis of some DMRs by BS-Seq validated the loss of methylation upon salt stress (Figure S3). Although all methylation contexts were present (CG, $\mathrm{CHG}$, and $\mathrm{CHH}$ ), in DMR2 the methylation was mainly in the $\mathrm{CHH}$ context, while in DMR15 the CHG context was predominant. This analysis also revealed variation in methylated cytosines content among different DMRs. The DMR2 is considerably less methylated than DMR15 (2.012\% and 5.51\%, respectively) but both DMRs suffered a loss of methylation upon salt stress (1.066\% and $4.494 \%$ for DMR2 and DMR15, respectively).

Table 1. Summary of methylated DNA immunoprecipitation (MeDIP-seq) data analysis. The input refers to a control library that did not go through the MeDIP procedure.

\begin{tabular}{|c|c|c|c|c|c|c|c|c|c|c|c|}
\hline \multirow{2}{*}{ Condition } & \multirow{2}{*}{$\begin{array}{l}\text { Biological } \\
\text { Replicates }\end{array}$} & \multirow{2}{*}{$\begin{array}{l}\text { Total } \\
\text { Reads }\end{array}$} & \multirow{2}{*}{$\begin{array}{c}\text { \# Uniquely } \\
\text { Mapped } \\
\text { Reads }\end{array}$} & \multirow{2}{*}{$\begin{array}{c}\text { \% Uniquely } \\
\text { Mapped } \\
\text { Reads }\end{array}$} & \multicolumn{7}{|c|}{$\begin{array}{l}\text { Cytosine Coverage \% } \\
(\text { Total C's = 63095915) }\end{array}$} \\
\hline & & & & & $0 \times$ & $1 \times$ & $2 \times$ & $3 \times$ & $4 \times$ & $5 \times$ & $>5 \times$ \\
\hline Control 1 & 2 & 17.225 .011 & 4.283 .278 & 24.87 & 82.82 & 8.05 & 2.48 & 1.37 & 0.92 & 0.67 & 3.7 \\
\hline Control 2 & 2 & 16.081 .432 & 4.075 .168 & 25.34 & 84.54 & 6.63 & 2.32 & 1.34 & 0.91 & 0.66 & 3.59 \\
\hline Stress 1 & 2 & 13.681 .641 & 3.639 .466 & 26.60 & 82.86 & 8.89 & 2.46 & 1.29 & 0.84 & 0.61 & 3.05 \\
\hline Stress 2 & 2 & 13.845 .643 & 3.562 .794 & 25.73 & 84.54 & 6.63 & 2.32 & 1.34 & 0.91 & 0.66 & 3.59 \\
\hline Input & 1 & 14.661 .478 & 7.016 .939 & 47.86 & 51.2 & 22.17 & 14.59 & 7.39 & 3.03 & 1.06 & 0.57 \\
\hline
\end{tabular}




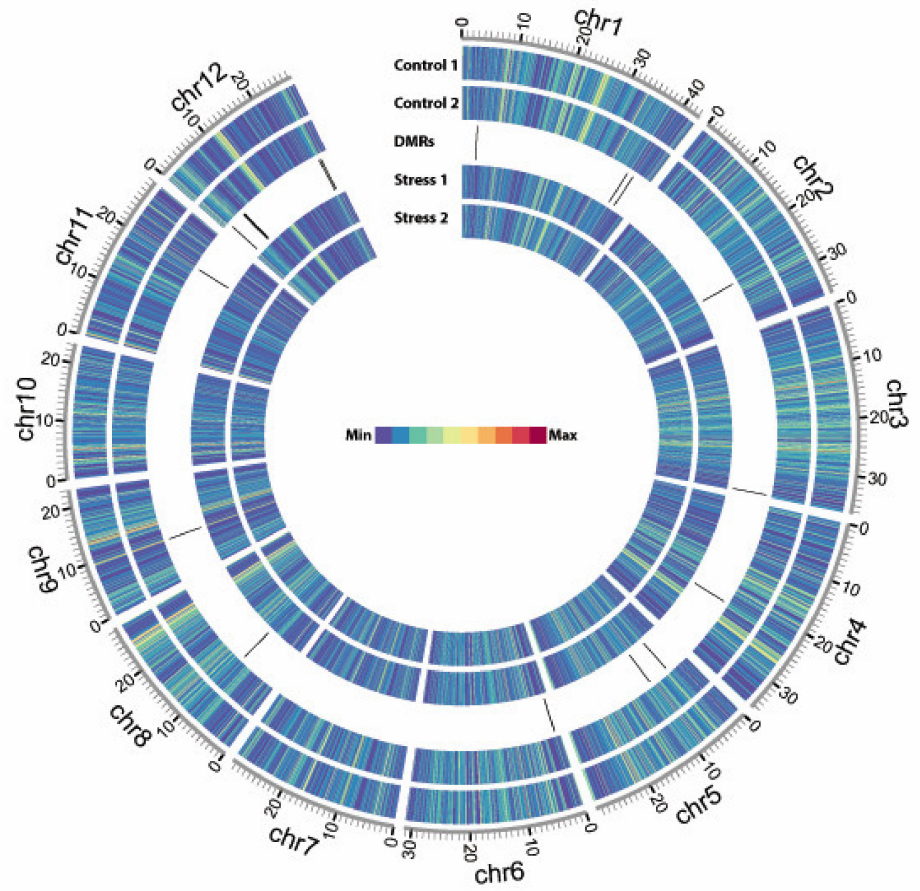

A

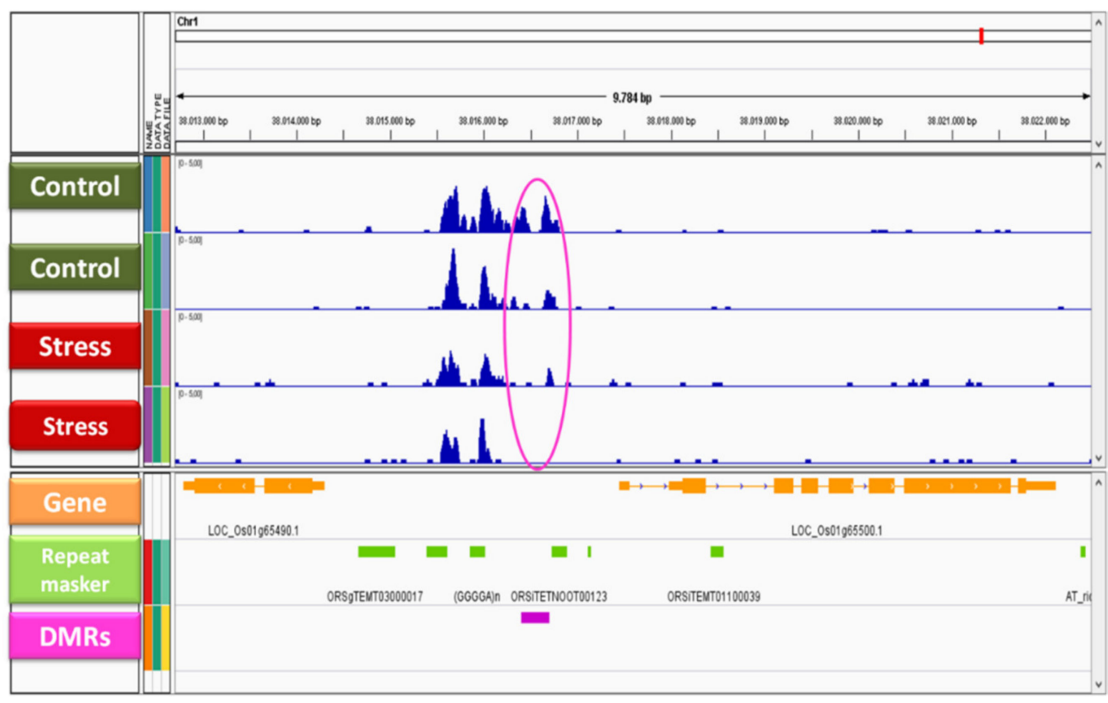

B

Figure 1. Identification of differentially methylated regions (DMRs) between control and salt stress samples in a salt-tolerant rice variety. (A) A genome-wide view of DNA methylation of Pokkali leaves. The circos plot representation was used to show the location of DMRs between control and salt stress conditions. The circos plot was based on the average RPM over 100,000 bp windows. (B) An example of a DMR (DMR 2) (pink bar and circle) exhibiting lower levels of DNA methylation in salt stress than in control conditions. The annotation of genes and repetitive sequences physically related to DMR is shown at the bottom. All the DMRs identified are shown in Figure S2. 
Table 2. List of DMRs between control and salt stress imposed on 14 days-old rice seedlings. The position of DMRs at chromosome level is schematically represented. Genes nearby DMRs are indicated.

\begin{tabular}{|c|c|c|c|c|c|c|}
\hline Chr & DMR ID & $\begin{array}{l}\text { Coordinat. } \\
\text { Start End }\end{array}$ & $\begin{array}{l}\text { Repeat Masker } \\
\text { Annotation }\end{array}$ & Gene Annotation & $\begin{array}{l}\text { DMR Position } \\
\text { Relative to the Gene }\end{array}$ & Gene Description \\
\hline \multirow{6}{*}{$\stackrel{\mathrm{I}}{\ominus}$} & \multirow{2}{*}{1} & \multirow{2}{*}{$\begin{array}{l}3431001 \\
3431100\end{array}$} & \multirow{2}{*}{$\begin{array}{l}\text { AnacC1 transposon } \\
\text { (ORSiTETNOOT00122) }\end{array}$} & LOC_Os01g07270 & 78 bp downstream & Transposon \\
\hline & & & & LOC_Os01g07280 & 506 bp downstream & $\begin{array}{l}\text { Disease-resistance } \\
\text { protein }\end{array}$ \\
\hline & \multirow{2}{*}{2} & \multirow{2}{*}{$\begin{array}{l}38016401 \\
38016700\end{array}$} & \multirow{2}{*}{-} & LOC_Os01g65490 & $2100 \mathrm{bp}$ upstream & DNA binding protein \\
\hline & & & & LOC_Os01g65500 & 750 bp upstream & $\begin{array}{l}\text { Chloride channel } \\
\text { protein }\end{array}$ \\
\hline & \multirow{2}{*}{3} & \multirow{2}{*}{$\begin{array}{l}39466301 \\
39466500\end{array}$} & \multirow{2}{*}{ (CGG)n rich area } & LOC_Os01g67910 & $5^{\prime}$ overlap & Expressed protein \\
\hline & & & & LOC_Os01g67920 & 796 bp downstream & $\begin{array}{l}\text { Tetratricopeptide repeat } \\
\text { protein }\end{array}$ \\
\hline II & 4 & $\begin{array}{l}26500001 \\
26500100\end{array}$ & - & LOC_Os02g43890 & $\begin{array}{c}\text { Within } \\
\text { (intron/exon/intron) }\end{array}$ & Hypothetical protein \\
\hline III & \multirow[t]{2}{*}{5} & \multirow[t]{2}{*}{$\begin{array}{l}36070201 \\
36071200\end{array}$} & \multirow[t]{2}{*}{$\begin{array}{l}\text { AnacA2 transposon } \\
\text { (ORSiTETNOOT00130) }\end{array}$} & $\begin{array}{l}\text { LOC_Os03g63840 } \\
\text { LOC_Os03g63850 }\end{array}$ & \multirow[t]{2}{*}{$\begin{array}{l}4194 \text { bp downstream } \\
1972 \text { bp upstream }\end{array}$} & \multirow[t]{2}{*}{$\begin{array}{l}\text { Expressed protein } \\
\text { OsFBDUF19 protein }\end{array}$} \\
\hline L & & & & & & \\
\hline $\begin{array}{l}\text { IV } \\
\text { Q }\end{array}$ & \multirow[b]{2}{*}{6} & \multirow{2}{*}{$\begin{array}{l}22831201 \\
22831400\end{array}$} & \multirow[b]{2}{*}{ (CGG)n rich area } & LOC_Os04g38390 & 780 bp downstream & \multirow{2}{*}{$\begin{array}{l}\text { Wound/stress protein } \\
\text { Ethylene-insensitive } \\
3 \text { protein }\end{array}$} \\
\hline f & & & & LOC_Os04g38400 & 2620 bp upstream & \\
\hline \multirow{4}{*}{$\stackrel{\mathrm{V}}{\mathrm{E}}$} & 7 & $\begin{array}{l}4804401 \\
4804700\end{array}$ & $\begin{array}{l}\text { AnacA10 transposon } \\
\text { (ORSiTETNOOT00124) }\end{array}$ & LOC_Os05g08760 & Within (exon/intron) & Expressed protein \\
\hline & 8 & $\begin{array}{l}4805301 \\
4805500\end{array}$ & - & LOC_Os05g08760 & Within (exon) & Expressed protein \\
\hline & 9 & 9320201 & RIRE3 gypsy-type & LOC_Os05g16420 & 1570 bp downstream & $\begin{array}{l}\text { SHR5-receptor-like } \\
\text { kinase protein }\end{array}$ \\
\hline & & & (ORSiTERTOOT00027) & LOC_Os05g16430 & $1300 \mathrm{bp}$ upstream & $\begin{array}{l}\text { SHR5-receptor-like } \\
\text { kinase protein }\end{array}$ \\
\hline & 10 & $\begin{array}{l}962901 \\
963200\end{array}$ & $\begin{array}{l}\text { E4 repeat sequence } \\
\text { (ORSiOTOT00000050) }\end{array}$ & $\begin{array}{l}\text { LOC_Os06g02680 } \\
\text { LOC_Os06g02690 }\end{array}$ & $\begin{array}{l}680 \text { bp upstream } \\
20 \text { bp downstream }\end{array}$ & $\begin{array}{l}\text { Expressed protein } \\
\text { Expressed protein }\end{array}$ \\
\hline & 11 & $\begin{array}{l}970501 \\
970600\end{array}$ & - & LOC_Os06g02700 & Within (exon) & Retrotransposon \\
\hline O & 12 & $\begin{array}{l}983401 \\
983500\end{array}$ & - & LOC_Os06g02730 & 3591 bp upstream & $\begin{array}{c}\text { Aspartic proteinase } \\
\text { nepenthesin-2 precursor } \\
\text { protein }\end{array}$ \\
\hline & & & & LOC_Os06g02740 & 7261 bp upstream & Retrotransposon \\
\hline & 13 & $\begin{array}{l}1010401 \\
1010700\end{array}$ & (CGG)n rich area & LOC_Os06g02770 & Within (exon) & Expressed gene \\
\hline VIII & 14 & 9021501 & - & LOC_Os08g14950 & $1150 \mathrm{bp}$ downstream & $\begin{array}{l}\text { Receptor-like kinase } 2 \\
\text { precursor protein }\end{array}$ \\
\hline 8 & & 9021600 & & LOC_Os08g14960 & 4240 bp upstream & $\begin{array}{l}\text { Receptor-like kinase } \\
\text { precursor protein }\end{array}$ \\
\hline IX & 15 & 9475001 & $\begin{array}{l}\text { Ty3-gypsy } \\
\text { retrotransposon }\end{array}$ & LOC_Os09g15470 & 3500 bp upstream & $\begin{array}{l}\text { Retrotransposon } \\
\text { Ty3-gypsy }\end{array}$ \\
\hline U & & 9475300 & (ORSiTERT00200079) & LOC_Os09g15480 & 1100bp downstream & Ser/Thr-rich protein \\
\hline XI & 16 & $\begin{array}{l}20435601 \\
20436000\end{array}$ & - & LOC_Os11g34870 & Within (intron) & Expressed protein \\
\hline & 17 & $\begin{array}{l}1446901 \\
1447100\end{array}$ & $\begin{array}{l}\text { AnacA10 transposon } \\
\text { (ORSiTETNOOT00124) }\end{array}$ & $\begin{array}{l}\text { LOC_Os12g03601 } \\
\text { LOC_Os12g03610 }\end{array}$ & $\begin{array}{l}519 \text { bp upstream } \\
2283 \text { bp upstream }\end{array}$ & $\begin{array}{l}\text { Expressed protein } \\
\text { Expressed protein }\end{array}$ \\
\hline & 18 & 4989301 & noaCRR2 & LOC_Os12g09500 & 975 bp upstream & $\begin{array}{l}\text { Cytochrome P450 } \\
\text { protein }\end{array}$ \\
\hline & 18 & 4989600 & $\begin{array}{l}\text { retrotransposon } \\
\text { (ORSiTERTOOT00141) }\end{array}$ & LOC_Os12g09510 & 8570 bp upstream & \\
\hline XII & 19 & $\begin{array}{l}5108601 \\
5108800\end{array}$ & $\begin{array}{l}\text { Ty3-gypsy } \\
\text { retrotransposon } \\
\text { (ORSiTERT00200079) }\end{array}$ & LOC_Os12g09680 & Within (intron) & $\begin{array}{l}\text { Retrotransposon } \\
\text { Ty3-gypsy }\end{array}$ \\
\hline & & 5301501 & Centromere-like LTR & LOC_Os12g10000 & 2500 bp upstream & Retrotransposon \\
\hline$=$ & 20 & 5301700 & transposon & LOC_Os12g10010 & 34 bp downstream & Expressed protein \\
\hline & & 25340601 & (ORSiCMCM00100011) & LOC_Os12g40930 & 155 bp upstream & Expressed protein \\
\hline & 21 & 25341000 & (GGA)n rich area & LOC_Os12g40940 & 4377 bp upstream & Expressed protein \\
\hline & & 25763601 & noaCRR2 & LOC_Os12g41630 & 4000 bp upstream & $\begin{array}{l}\text { OsFBX463-F-box } \\
\text { domain protein }\end{array}$ \\
\hline & 22 & 2764100 & $\begin{array}{l}\text { retrotransposon } \\
\text { (ORSiTERTOPT }\end{array}$ & LOC_Os12g41634 & Within (exon) & Expressed protein \\
\hline & & & & LOC_Os12g41640 & 800 bp upstream & Expressed protein \\
\hline
\end{tabular}




\subsection{Location of DMRs Might Influence Regulation of Genes Nearby}

The methylome is certainly shaped in response to stress but it is less clear how to connect changes on specific methylome patterns with modulation of gene expression. The DMRs location along rice chromosomes is shown in Table 2. A higher number of DMRs was detected in chromosomes VI and XII, four and six DMRS, respectively as shown in Table 2, while no DMRs were detected on chromosomes VII and X. Intersecting the MeDIP-Seq data with the rice genome annotation (http:/ / rice.plantbiology. msu.edu/) and the Repeat Masker software (http:/ /www.repeatmasker.org/), we could further obtain a genomic landscape for all DMRs (Figure S2). DMR2 is located on chromosome I, upstream a chloride channel protein coding gene (LOC_Os01g65500) and a DNA binding protein coding gene (LOC_Os01g65490), indicating that one DMR can potentially influence more than one gene (Figure 1B). The DMRs were analyzed according to their position relative to the nearest gene, and more than $70 \%$ of the DMRs were in close proximity to genes (less than $2 \mathrm{kbp}$ away) (Figure 2A). Furthermore, over $75 \%$ of the DMRs identified were associated with transposable elements and repetitive sequences (Figure 2B).

A

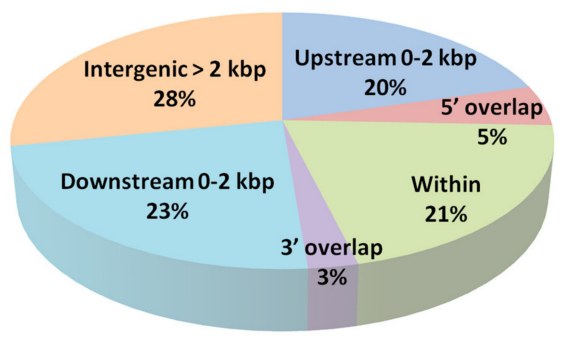

B

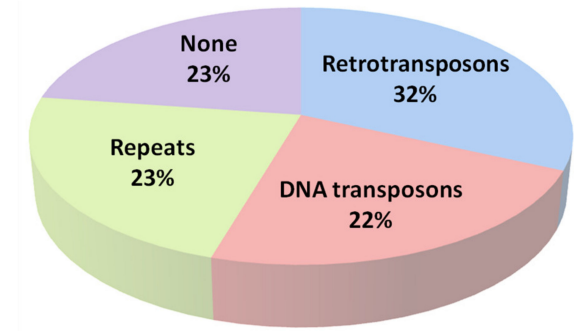

Figure 2. Classification of DMRs according to genomic features. (A) DMRs location in relation to their position to the nearest genes: Upstream [ $>2 \mathrm{kbp}$ or between 0 and $2 \mathrm{kbp}$ of the gene transcription starting site (TSS)], 5' overlapping [in case the DMR overlaps to gene transcription starting site]; within [if the DMR falls completely within the borders of a gene]; 3 ' overlapping, [in case the DMR overlaps with the 3' end of an annotated gene]; or downstream [0 to $2 \mathrm{kbp}$ or $>2 \mathrm{kbp}$ from gene end]. (B) DMRs location in relation to Repeat Masks annotation: Retrotransposons, Transposons, and Repeats [(CGG)n and (GGA)n rich areas].

We further wanted to investigate the expression of several genes located nearby DMRs, before and after salt treatment by RT-qPCR. Based on the criterion of proximity to the identified DMRs, specific genes were selected for expression studies (Figure 3). The selected case studies included DMR2, located upstream two genes in opposite orientation (a DNA binding protein and a Chloride channel protein) (Figure 3A) and DMR9 (Figure 3C) located upstream a receptor-like kinase. Another three genes were selected for expression analyses because of carrying a DMR within the gene body (Figure 3B,D,E). The genes coding for a DNA binding protein and a retrotransposon (Figure 3A,D) showed a significant induction by salt stress, while a gene encoding a hypothetical protein (Figure 3B) was found to reduce expression upon stress. Regarding the other genes analyzed, no drastic changes were found upon stress. 
A
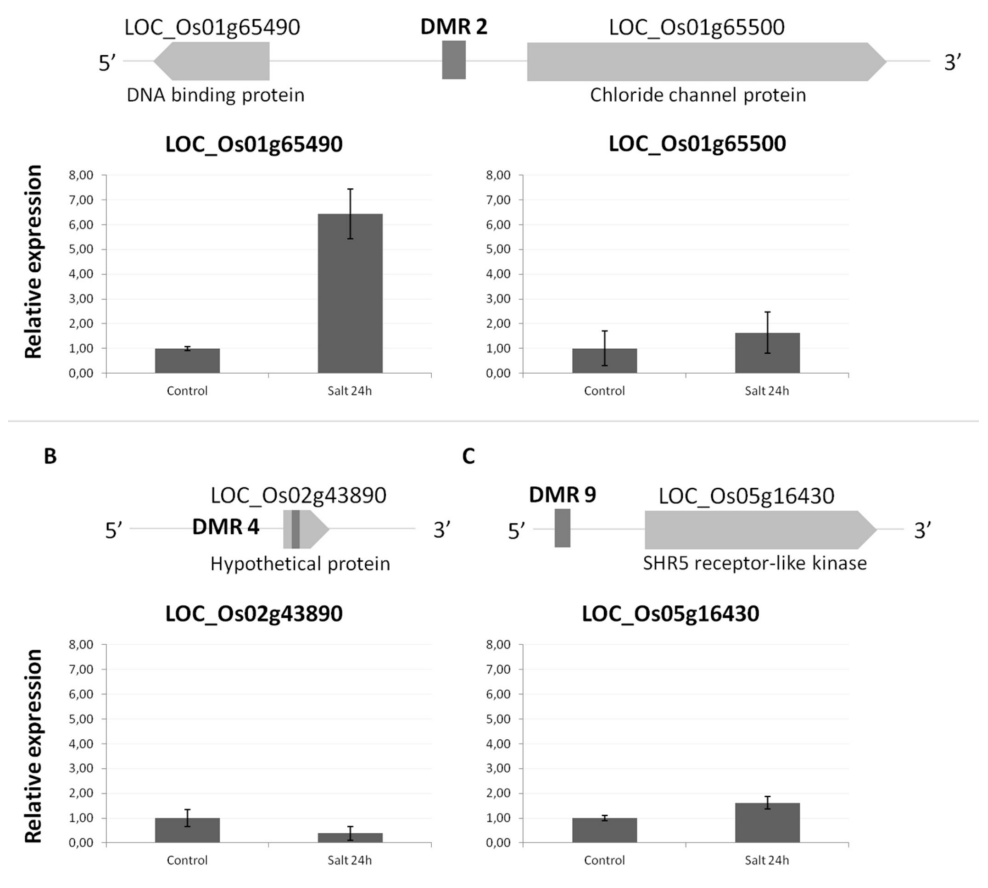

LOC_Os05g16430
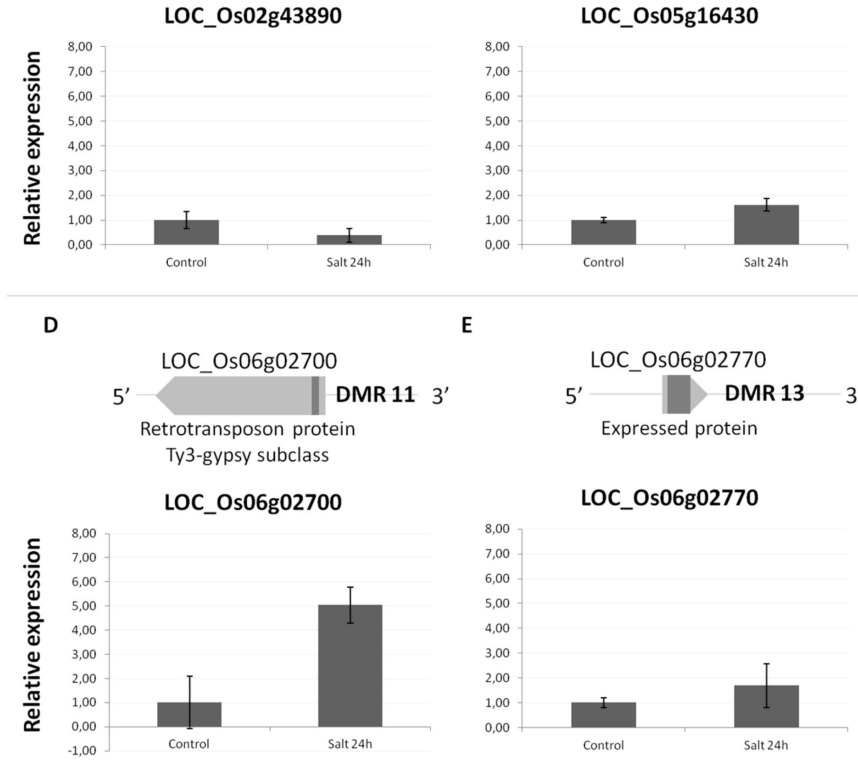

E

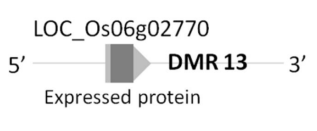

LOC_Os06g02770

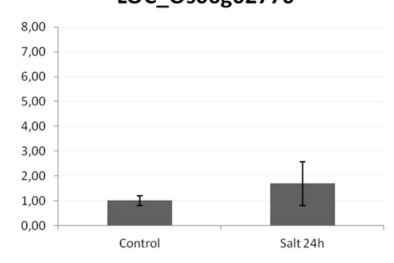

Figure 3. Expression studies of genes nearby DMRs by quantitative real-time qPCR. Genes containing DMRs at promoter regions are shown in (A) and (C) while genes containing DMRs within the coding region are shown in (B), (D), and (E). The mean expression value of control was normalized to 1 and the other mean values represent fold changes in expression of three technical replicates. The graphics show the result of one representative biological assay, from a total of three different replicates.

The functional annotation of genes flanking or overlapping salt-induced DMRs was performed using Blast2GO [35] and multilevel pie charts were generated for the three main classes: cellular component, biological process, and molecular function (Figure S4). Regarding the molecular function, nine functional categories were identified, the most common being the protein binding followed by nucleotide binding and kinase activity (Figure S4A). For the cellular component, most of the proteins indicate plastidial location, but occasional location in the nucleus or in the plasma membrane was also identified (Figure S4B). The main biological processes annotated to those proteins are cellular protein modification processes, biosynthetic processes, carbohydrate, and DNA metabolic processes (Figure S4C).

\section{Discussion}

The study of epigenetic alterations in salt-tolerant plants can contribute to uncover the meaning of methylome changes in gene regulation and in stress tolerance. We previously reported that 'Pokkali', a salinity-tolerant rice variety, can display a quick relaxation of DNA methylation levels in response 
to salinity [13]. In this study, we wanted to deepen the methylome dynamics of 'Pokkali' and used the MeDIP-Seq approach to decipher differentially methylated regions (DMRs) between control and salt stress conditions. The MeDIP-Seq is a relatively affordable method to provide methylation information, although it does not allow an absolute quantification of the methylation nor is it sensitive enough to allow a high genome coverage [36,37]. In 'Pokkali', we found methylated areas mostly dispersed throughout all chromosomes with no clear evidences for high methylation density at specific chromosome regions as centromeres. Other studies in rice showed that centromeres are not densely methylated and even possess euchromatic subdomains at centromeric regions, compatible at same degree with gene transcription [38,39]. Furthermore, the rice interphase nuclei labeled with DAPI shows a diffuse chromatin organization pattern with no evidences of markedly labeled heterochromatic regions [40]. Contrastingly, DAPI staining applied to Arabidopsis nuclei easily enable the visualization of heterochromatic knobs [41] and the centromeric regions of Arabidopsis chromosomes were described as particularly rich in DNA methylation [42-44].

The investigation of genomic regions in leaf tissues of 'Pokkali' that could be preferentially selected for differential methylation in control and salt stress samples revealed a general tendency for DMRs to lose methylation upon salinity imposition which is in agreement with previous reports of demethylation associated with salt stress treatments [11-13]. By adopting strict filtering criteria in the bioinformatics analysis of the MeDIP-Seq data, 53 DMRs were identified either within genes or in its vicinity (less than $2 \mathrm{kbp}$ apart) and far from centromeres. A plausible hypothesis is that DMRs may modulate chromatin structure and in this way influence the transcriptional competence of specific genes depending on the DMRs location. A single DMR can be a regulation region influencing the expression level of several genes even if they locate physically apart [45]. The identification and location of DMRs, either in the exons, introns, or even in the exon/intron transition, may also bring new clues regarding the involvement of DNA methylation in splicing mechanisms since various splicing factors were found to be involved at different steps of RdDM pathway [46]. In our study of gene expression changes relative to DMR location, we found two genes adjacent to DMRs that showed increased expression, in accord with the stress-induced hypomethylation of DMRs. On the other hand, the expression of the other genes analyzed was not dramatically changed or even appeared to decrease. In a microarray study in 'Pokkali' roots Hruz et al. [47] found that LOC_Os09g15480 (encoding a serine/threonine-rich protein), a gene that we found close to DMR15, is repressed by salt stress.

The identification of DMRs in stress tolerant plants can be a tool to unveil epigenetic regulation of novel salt-responsive genes with putative functional relevance in salt tolerance mechanisms, bringing new clues about how to apply the knowledge of specific methylation variations in stress tolerance management.

\section{Materials and Methods}

\subsection{Plant Material, Growth Conditions, and Salt Stress Treatment}

The salt-tolerant rice variety Oryza sativa ssp indica cv. Pokkali was used in this study. Seed germination and salt stress imposition followed the procedures described in Ferreira et al. [13]. Briefly, seeds were surface disinfected with a benlate solution $(0.1 \%)$ for $30 \mathrm{~min}$ at $50{ }^{\circ} \mathrm{C}$, rinsed with sterile water, soaked in $70 \%$ ethanol for $1 \mathrm{~min}$, and washed with a solution of $2 \%$ sodium hypochlorite containing $0.02 \%$ Tween 20 for $30 \mathrm{~min}$. After several washes in sterile water, seeds were germinated in Petri dishes containing $3 \mathrm{~mm}$ paper embedded in sterile water, in the dark, for 3 days, at $28^{\circ} \mathrm{C}$. Germinated seedlings were transferred to glass tubes containing Yoshida's medium [48] and allowed to grow in a growth chamber at $28^{\circ} \mathrm{C} / 24^{\circ} \mathrm{C}$ and $12 \mathrm{~h}$ photoperiod $\left(500 \mu \mathrm{Em}^{-2} \mathrm{~s}^{-1}\right)$ with $70 \%$ humidity. For each condition-salt or control-a pool of 15 seedlings were used. The salt stress treatment was applied to 14-day-old seedlings and consisted in supplementing the Yoshida's medium with $200 \mathrm{mM}$ $\mathrm{NaCl}$. Rice leaves were collected after $24 \mathrm{~h}$ of salt treatment, frozen in liquid nitrogen, and kept at $-80^{\circ} \mathrm{C}$. 


\subsection{Methylated DNA Immunoprecipitation Sequencing (MeDIP-Seq)}

Genomic DNA from 'Pokkali' leaves was isolated using the DNeasy ${ }^{\circledR}$ Plant mini kit (Qiagen, Hilden, Germany) according to the manufacturer instructions. DNA quality was assessed in agarose gel electrophoresis and absorbance spectroscopy using the Nanodrop. DNA was then sonicated to obtain short fragments of approximately 150-400 bp which were then incubated with a monoclonal antibody highly specific to recognize 5-methylcytosine (catalogue $\mathrm{n}^{\circ}$ 39649, Active Motif). The methylated enriched fraction of the immunoprecipitated DNA was high-throughput sequenced using the Illumina Hi-Seq platform as a service provided by Active Motif. The immunoprecipitated DNA was amplified using barcoded Illumina primers to generate the final library for sequencing. A control input library was prepared by amplifying a small amount of DNA (pooling all samples) that did not go through the MeDIP step. Two biological replicates were used per each condition.

\subsection{Mapping and Processing the MeDIP-Seq Reads}

The reference genome sequence and gene annotation information available for Rice (Oryza sativa ssp. japonica, cv. Nipponbare) is of high quality [49] and the reads were mapped to the Michigan State University Genome Annotation Project Database, version 6.1 (http: / rice.plantbiology.msu.edu). To map the raw $50 \mathrm{nt}$ single-end reads, the original reads were computationally processed with the following steps. (1) Quality check of the raw reads using FastQC tool; (2) sequence trimming using Trimmomatic [50], namely the cutting of adapters and other Illumina-specific sequences from the reads, sliding window trimming, standardization to a specified length; (3) mapping and alignment of the processed reads using the program GMAP (Genomic Mapping and Alignment Program) [51]; and (4) duplicate reads were removed with Samtools (public domain: http:/ / samtools.sourceforge. net/ [52]. Only uniquely mapped reads were further analyzed.

\subsection{Identification of Differentially Methylated Regions (DMRs)}

Uniquely mapped reads were analyzed using the MEDIPS software package [53] to estimate methylation levels (using a 20\% cut off). The genome was divided into $100 \mathrm{bp}$ windows and each of these was then tested for differential methylation (FDR $>0.1, \log 2 \mathrm{FC}(1.2)$ with minimum mean counts per group $=2$. Genomic regions showing statistically significant differential methylation when comparing salt stress versus control conditions were considered as differential methylated regions (DMRs).

\subsection{Bisulfite Sequencing (BS) of DMRs}

The BS method was used to validate the MeDIP-Seq data by tracking the methylation status of specific identified DMRs. Five hundred nanograms of genomic DNA were subjected to bisulfite conversion using the EZ DNA methylation ${ }^{\mathrm{TM}}$ (Zymo Research, Irvine, CA, USA) according to the manufacture's protocol. Bisulfite-converted DNA (four microliters) was used for PCR amplification of selected regions, namely the DMRs 2 and 15 (see Supplementary Table S1 for primer sequences). The PCR product was cloned into the $\mathrm{PCR}^{\mathrm{TM}} 4-\mathrm{TOPO}^{\circledR}$ Vector (Invitrogen Life Sciences Technologies, Carlsbad, CA, USA) and used to transform E. coli DH $5 \alpha$-competent cells. The plasmidic DNA was extracted and purified with the Easy spin plasmid DNA minipreps kit (Cytomed, Lisbon, Portugal) and about 20 clones were then sent to sequence at Macrogen (http:/ / dna.macrogen.com/eng). The Kismeth platform reported in Gruntman et al. [54] was used to design the primers for amplification of the bisulfite converted DNA and for sequencing analysis of the multiple clones (http:/ / katahdin.mssm. edu/kismeth).

\subsection{Gene Expression Studies by Real-Time RT-PCR}

Total RNA from leaves of 'Pokkali' was isolated from a pool of 12 rice seedlings grown for 13 days in control conditions and another $24 \mathrm{~h}$ under salt stress $(200 \mathrm{mM} \mathrm{NaCl})$. The RNA extraction procedure 
followed the manufacturer's instructions (Zymo Resarch). The isolated total RNA was treated with TURBO DNA-free (Ambion, Invitrogen) to eliminate any possible DNA trace. The RNA integrity was checked by agarose gel electrophoresis and RNA concentration and purity was measured with Nanodrop. The cDNA synthesis was performed with $4 \mu \mathrm{g}$ of total RNA using the Random Hexamer primer and according to the instructions of the Transcriptor High Fidelity cDNA Synthesis Kit (Roche, Basel, Switzerland). The total cDNA obtained was diluted 5 times and $5 \mu \mathrm{L}$ were used for PCR amplification. Real-time quantitative PCR was performed using the LightCycler 480 system (Roche) and the SYBR Green I Master mix (Roche). PCR running conditions: one cycle at $95{ }^{\circ} \mathrm{C}$ for $5 \mathrm{~min}$ and 45 cycles at $95{ }^{\circ} \mathrm{C}$ for $10 \mathrm{~s}, 60{ }^{\circ} \mathrm{C}$ for $10 \mathrm{~s}$ and $72{ }^{\circ} \mathrm{C}$ for $10 \mathrm{~s}$. The $\mathrm{Ct}$ values were calculated from means of three technical PCR replicates. The relative expression level of each transcript was calculated using the method "relative quantification with kinetic PCR efficiency correction". The rice gene ubiquitin-conjugating enzyme E2 (OsUBC2, LOC_Os02g42314) was used to normalize the relative expression of the target transcripts given our previous experiments showing its stability under salt stress as referred in Ferreira et al. [13]. All experiments were done with at least three biological replicates. Primers for genes located nearby selected DMRs are listed in Supplementary Table S2.

Supplementary Materials: The following are available online at http:/ www.mdpi.com/2075-4655/3/1/4/s1, Figure S1: Chromosome-level view of DNA methylation in control (A) and salt stress (B) conditions. The chromosome read coverage plots were based on the average RPM over 100,000 bp windows. Figure S2: Methylation status of all DMRs identified between control and salt stress conditions. Figure S3: Bisulfite sequencing (BS) analysis for DMR2 and DMR15. The region analyzed by BS is indicated with a grey line under the DMR (black box). Positions of the first and last cytosines analyzed are indicated. Cytosine methylation contexts are symbolized by red circles for CG, green circles for $\mathrm{CHG}$ and blue circles for $\mathrm{CHH}(\mathrm{H}=\mathrm{A}, \mathrm{T}$ or $\mathrm{C})$. Methylation (at the different contexts and globally) is also indicated. Figure S4: Gene Ontology (GO) analysis. Multilevel pie chart representation of GO annotations for genes near salt stress-induced DMRs. Charts were built using Blast2GO and are represented according to (A) molecular function (B) cellular component (C) biological process. Table S1: List of primers used for Bisulfite Sequencing (BS)-PCR analysis of specific DMRs. For PCR amplification of DMRs, the Taq DNA polymerase (New England Biolabs) was used. Table S2: List of primers used for expression analyses of rice genes located nearby DMRs. Details on real-time RT-PCR conditions are described in material and methods.

Author Contributions: Conceptualization: L.J.F. and A.P.S.; Data Curation: L.J.F., M.T.A.D., and A.P.S.; Funding Acquisition: A.P.S. and M.M.O.; Investigation, L.J.F., and A.P.S.; Methodology: L.J.F., P.B., and A.P.S.; Resources: N.J.S.; Software: M.T.A.D.; Supervision: A.P.S.; Validation: A.P.S. and M.M.O.; Writing-Original Draft, L.J.F. and A.P.S.; Writing-Review \& Editing, L.J.F., A.P.S., and M.M.O. All authors read and approved the manuscript.

Acknowledgments: The work was supported by the FCT (Portuguese Foundation for Science and Technology) through the project "Epigenetic regulation of the rice genome under environmental stresses" '[BIA-BCM/111645/2009]', and through the R\&D unit, UID/Multi/04551/2013 (GREEN-IT). APS, LF, and PB were supported by FCT grants [BPD/74197/2010], [BD/61428/2009], and [BPD/86742/2012], respectively. The funders had no role in study design, data collection, and analysis; decision to publish; or preparation of the manuscript. The authors deeply acknowledge to Filipe Borges for suggestions and discussions and in particular to Dr. Rob Martienssen by kindly hosting LF at Cold Spring Harbor laboratory for performing the bioinformatics analysis of the MEDIP-Seq data.

Conflicts of Interest: The authors declare no conflicts of interest.

\section{References}

1. Munns, R.; Tester, M. Mechanisms of salinity tolerance. Annu. Rev. Plant Biol. 2008, 59, 651-681. [CrossRef] [PubMed]

2. Chinnusamy, V.; Jagendorf, A.; Zhu, J.K. Understanding and improving salt tolerance in plants. Crop Sci. 2005, 45, 437-448. [CrossRef]

3. Ghosh, B.; Ali Md, N.; Saikat, G. Response of Rice under Salinity Stress: A Review Update. J. Res. Rice 2016, 4, 167. [CrossRef]

4. Kumar, K.; Kumar, M.; Kim, S.R.; Ryu, H.; Cho, Y.G. Insights into genomics of salt stress response in rice. Rice 2013, 28, 27. [CrossRef] [PubMed]

5. Kumar, M.; Choi, J.; An, G.; Kim, S.R. Ectopic Expression of OsSta2 enhances salt stress tolerance in rice. Front. Plant Sci. 2012, 10, 316. [CrossRef] [PubMed] 
6. Kumar, M.; Sang-Choon, L.; Ji-Youn, K.; Soo-Jin, K.; San, S.A.; Seong-Ryong, K. Over-expression of Dehydrin Gene, OsDhn1, improves drought and salt stress tolerance through scavenging of reactive oxygen species in rice (Oryza sativa L.). J. Plant Biol. 2014, 57, 383-393. [CrossRef]

7. Xie, R.; Zhang, J.; Ma, Y.; Pan, X.; Dong, C.; Pang, S.; He, S.; Deng, L.; Yi, S.; Zheng, Y.; et al. Combined analysis of mRNA and miRNA identifies dehydration and salinity responsive key molecular players in citrus roots. Sci. Rep. 2017, 6, 42094. [CrossRef]

8. Fu, R.; Zhang, M.; Zhao, Y.; He, X.; Ding, C.; Wang, S.; Feng, Y.; Song, X.; Li, P.; Wang, B. Identification of salt tolerance-related microRNAs and their targets in maize (Zea mays L.) using high-throughput sequencing and degradome analysis. Front. Plant Sci. 2017, 26, 864. [CrossRef]

9. Santos, A.P.; Ferreira, L.; Maroco, J.; Oliveira, M.M. Abiotic stress and induced DNA hypomethylation cause interphase chromatin structural changes in rice rDNA loci. Cytogenet. Genome Res. 2011, 132, 297-303. [CrossRef]

10. Santos, A.P.; Ferreira, L.J.; Oliveira, M.M. Concerted flexibility of chromatin structure, methylome and histone modifications along with plant stress responses. Biology 2017, 6, 3. [CrossRef]

11. Wang, W.S.; Zhao, X.Q.; Pan, Y.; Zhu, L.H.; Fu, B.Y.; Li, Z.K. DNA methylation changes detected by methylation-sensitive amplified polymorphism in two contrasting rice genotypes under salt stress. J. Genet. Genom. 2011, 38, 419-424. [CrossRef] [PubMed]

12. Karan, R.; DeLeon, T.; Biradar, H.; Subudhi, P.K. Salt stress induced variation in DNA methylation pattern and its influence on gene expression in contrasting rice genotypes. PLoS ONE 2012, 7, e40203. [CrossRef] [PubMed]

13. Ferreira, L.J.; Azevedo, V.; Maroco, J.; Oliveira, M.M.; Santos, A.P. Salt tolerant and sensitive rice varieties display differential methylome flexibility under salt stress. PLoS ONE 2015, 10, e0124060. [CrossRef] [PubMed]

14. Hashida, S.N.; Kitamura, K.; Mikami, T.; Kishima, Y. Temperature shift coordinately changes the activity and the methylation state of transposon Tam3 in Antirrhinum majus. Plant Physiol. 2003, 132, 1207-1216. [CrossRef] [PubMed]

15. Lu, Y.C.; Feng, S.J.; Zhang, J.J.; Luo, F.; Zhang, S.; Yang, H. Genome-wide identification of DNA methylation provides insights into the association of gene expression in rice exposed to pesticide atrazine. Sci. Rep. 2016, 6, 18985. [CrossRef] [PubMed]

16. Santos, A.P.; Abranches, R.; Alison, E.; Stoger, E.; Viegas, W.; Shaw, P.J. The architecture of interphase chromosomes and gene positioning are altered by changes in DNA methylation and histone acetylation. J. Cell Sci. 2002, 115, 4597-4606. [CrossRef]

17. Wang, M.; Qin, L.M.; Xie, C.; Li, W.; Yuan, J.; Kong, L.; Yu, W.; Xia, G.; Liu, S. Induced and constitutive DNA methylation in a salinity-tolerant wheat introgression line. Plant Cell Physiol. 2014, 55, 1354-1365. [CrossRef]

18. Wang, W.; Huang, F.; Qin, Q.; Zhao, X.; Li, Z.; Fu, B. Comparative analysis of DNA methylation changes in two rice genotypes under salt stress and subsequent recovery. Biochem. Biophys. Res. Commun. 2015, 465, 790-796. [CrossRef]

19. Wang, W.; Qin, Q.; Sun, F.; Wang, Y.; Xu, D.; Li, Z.; Fu, B. Genome-Wide Differences in DNA Methylation Changes in Two Contrasting Rice Genotypes in Response to Drought Conditions. Front. Plant Sci. 2016, 7 , 1675. [CrossRef]

20. Garg, R.; Chevala, V.V.S.N.; Shankar, R.; Jain, M. Divergent DNA methylation patterns associated with gene expression in rice cultivars with contrasting drought and salinity stress response. Sci. Rep. 2015, 5, 14922. [CrossRef]

21. Pandey, G.; Yada, C.B.; Sahu, P.P.; Muthamilarasan, M.; Prasad, M. Salinity induced differential methylation patterns in contrasting cultivars of foxtail millet (Setaria italica L.). Plant Cell Rep. 2017, 36, 759-772. [CrossRef] [PubMed]

22. Liu, C.; Li, S.; Wang, M.C.; Xia, G.M. A transcriptomic analysis reveals the nature of salinity tolerance of a wheat introgression line. Plant Mol. Biol. 2012, 78, 159-169. [CrossRef] [PubMed]

23. Comai, L.; Tyagi, A.P.; Winter, K.; Holmes-Davis, R.; Reynolds, S.H.; Stevens, Y.; Byers, B. Phenotypic instability and rapid gene silencing in newly formed Arabidopsis allotetraploids. Plant Cell 2000, 12, 1551-1567. [CrossRef] [PubMed] 
24. Song, F.; Smith, J.F.; Kimura, M.T.; Morrow, A.D.; Matsuyama, T.; Nagase, H.; Held, W.A. Association of tissue-specific differentially methylated regions (TDMs) with differential gene expression. PNAS 2005, 102, 9, 3336-3341. [CrossRef] [PubMed]

25. Rakyan, V.K.; Down, T.A.; Thorne, N.P.; Flicek, P.; Kulesha, E.; Gräf, S.; Tomazou, E.M.; Bäckdahl, L.; Johnson, N.; Herberth, M.; et al. An integrated resource for genome-wide identification and analysis of human tissue-specific differentially methylated regions (tDMRs). Genome Res. 2008, 18, 1518-1529. [CrossRef] [PubMed]

26. Doi, A.; Park, I.H.; Wen, B.; Murakami, P.; Aryee, M.J.; Irizarry, R.; Herb, B.; Ladd-Acosta, C.; Rho, J.; Loewer, S.; et al. Differential methylation of tissue- and cancer-specific CpG island shores distinguishes human induced pluripotent stem cells, embryonic stem cells and fibroblasts. Nat. Genet. 2009, 41, 1350-1353. [CrossRef] [PubMed]

27. Slieker, R.C.; Bos, S.D.; Goeman, J.J.; Bovée, J.V.; Talens, R.P.; van der Breggen, R.; Suchiman, H.E.; Lameijer, E.W.; Putter, H.; van den Akker, E.B.; et al. Identification and systematic annotation of tissue-specific differentially methylated regions using the Illumina 450k array. Epigenet. Chromatin 2013, 6, 26. [CrossRef]

28. Wan, J.; Oliver, V.F.; Wang, G.; Zhu, H.; Zack, D.J.; Merbs, S.L.; Qian, J. Characterization of tissue-specific differential DNA methylation suggests distinct modes of positive and negative gene expression regulation. BMC Genom. 2015, 16, 49. [CrossRef]

29. Vining, K.; Pomraning, K.R.; Wilhelm, L.J.; Ma, C.; Pellegrini, M.; Di, Y.; Mockler, T.C.; Freitag, M.; Strauss, S.H. Methylome reorganization during in vitro dedifferentiation and regeneration of Populus trichocarpa. BMC Plant Biol. 2013, 13, 92. [CrossRef]

30. Eichten, S.R.; Briskine, R.; Song, J.; Li, Q.; Swanson-Wagner, R.; Hermanson, P.J.; Waters, A.J.; Starr, E.; West, P.T.; Tiffin, P.; et al. Epigenetic and genetic influences on DNA methylation variation in maize populations. Plant Cell 2013, 8, 2783-2797. [CrossRef]

31. Schmitz, R.J.; He, Y.; Valdés-López, O.; Khan, S.M.; Joshi, T.; Urich, M.A.; Nery, J.R.; Diers, B.; Xu, D.; Stacey, G.; et al. Epigenome-wide inheritance of cytosine methylation variants in a recombinant inbred population. Genome Res. 2013, 23, 1663-1674. [CrossRef] [PubMed]

32. Chodavarapu, R.K.; Feng, S.; Ding, B.; Simon, S.A.; Lopez, D.; Jia, Y.; Wang, G.L.; Meyers, B.C.; Jacobsen, S.E.; Pellegrini, M. Transcriptome and methylome interactions in rice hybrids. Proc. Natl. Acad. Sci. USA 2012, 109, 12040-12045. [CrossRef] [PubMed]

33. Colaneri, A.C.; Jones, A.M. Genome-wide quantitative identification of DNA differentially methylated sites in Arabidopsis seedlings growing at different water potential. PLoS ONE 2013, 8, e59878. [CrossRef] [PubMed]

34. Zheng, X.; Chen, L.; Li, M.; Lou, Q.; Xia, H.; Wang, P.; Li, T.; Liu, H.; Luo, L. Transgenerational variations in DNA methylation induced by drought stress in two rice varieties with distinguished difference to drought resistance. PLoS ONE 2013, 8, e80253. [CrossRef] [PubMed]

35. Götz, S.; García-Gómez, J.M.; Terol, J.; Williams, T.D.; Nagaraj, S.H.; Nueda, M.J.; Robles, M.; Talón, M.; Dopazo, J.; Conesa, A. High-throughput functional annotation and data mining with the Blast2GO suite. Nucleic Acids Res. 2008, 36, 3420-3435. [CrossRef] [PubMed]

36. Bock, C.; Tomazou, E.M.; Brinkman, A.B.; Müller, F.; Simmer, F.; Gu, H.; Jäger, N.; Gnirke, A.; Stunnenberg, H.G.; Meissner, A. Quantitative comparison of genome-wide DNA methylation mapping technologies. Nat. Biotechnol. 2010, 28, 1106-1114. [CrossRef]

37. Yong, W.-S.; Hsu, F.-M.; Chen, P.-Y. Profiling genome-wide DNA methylation. Epigenet. Chromatin 2016, 9, 26. [CrossRef]

38. Nagaki, K.; Cheng, Z.; Ouyang, S.; Talbert, P.B.; Kim, M.; Jones, K.M.; Henikoff, S.; Buell, C.R.; Jian, J. Sequencing of a rice centromere uncovers active genes. Nat. Genet. 2004, 36, 138-145. [CrossRef]

39. Wu, Y.; Kikuchi, S.; Yan, H.; Zhang, W.; Rosenbaum, H.; Iniguez, A.L.; Jiang, J. Euchromatic subdomains in rice centromeres are associated with genes and transcription. Plant Cell 2011, 23, 4054-4064. [CrossRef]

40. Santos, A.P.; Shaw, P.J. Interphase chromosomes and the Rabl configuration: Does genome size matter? J. Microsc. 2004, 214, 201-206. [CrossRef]

41. Fransz, P.; de Jong, J.H.; Lysak, M.; Castiglione, M.R.; Schubert, I. Interphase chromosomes in Arabidopsis are organized as well defined chromocenters from which euchromatin loops emanate. PNAS 2002, 99, 14584-14589. [CrossRef] [PubMed] 
42. Haupt, W.; Fischer, T.C.; Winderl, S.; Fransz, P.; Torres-Ruiz, R.A. The centromere1 (CEN1) region of Arabidopsis thaliana: Architecture and functional impact of chromatin. Plant J. 2001, 27, 285-296. [CrossRef] [PubMed]

43. Zilberman, D.; Gehring, M.; Tran, R.K.; Ballinger, T.; Henikoff, S. Genome-wide analysis of Arabidopsis thaliana DNA methylation uncovers an interdependence between methylation and transcription. Nat. Genet. 2007, 39, 61-69. [CrossRef] [PubMed]

44. Lister, R.; O’Malley, R.C.; Tonti-Filippini, J.; Gregory, B.D.; Berry, C.C.; Millar, A.H.; Ecker, J.R. Highly integrated single-base resolution maps of the epigenome in Arabidopsis. Cell 2008, 133, 523-536. [CrossRef] [PubMed]

45. Blackwood, E.M.; Kadonaga, J.T. Going the distance: A current view of enhancer action. Science 1998, 281, 60-63. [CrossRef] [PubMed]

46. Huang, C.F.; Zhu, J.K. RNA Splicing Factors and RNA-Directed DNA Methylation. Biology 2014, 3, $243-254$. [CrossRef] [PubMed]

47. Hruz, T.; Laule, O.; Szabo, G.; Wessendorp, F.; Bleuler, S.; Oertle, L.; Widmayer, P.; Gruissem, W.; Zimmermann, P. GENEVESTIGATOR V3: A reference expression database for the meta-analysis of transcriptomes. Adv. Bioinform. 2008. [CrossRef]

48. Yoshida, S.; Foorno, D.; Cock, J.; Gomez, K. Laboratory Manual for Physiological Studies of Rice, 3rd ed.; International Rice Research Institute: Manila, Philippines, 1976.

49. Kawahara, Y.; de la Bastide, M.; Hamilton, J.P.; Kanamori, H.; McCombie, W.R.; Ouyang, S.; Schwartz, D.C.; Tanaka, T.; Wu, J.; Zhou, S.; et al. Improvement of the Oryza sativa Nipponbare reference genome using next generation sequence and optical map data. Rice 2013, 6, 4. [CrossRef]

50. Lohse, M.; Bolger, A.M.; Nagel, A.; Fernie, A.R.; Lunn, J.E.; Stitt, M.; Usadel, B. RobiNA: A user-friendly, integrated software solution for RNA-Seq-based transcriptomics. Nucleic Acids Res. 2012, 40, $622-627$. [CrossRef]

51. Wu, T.D.; Watanabe, C.K. GMAP: A genomic mapping and alignment program for mRNA and EST sequences. Bioinformatics 2005, 21, 1859-1875. [CrossRef]

52. Li, H.; Handsaker, B.; Wysoker, A.; Fennell, T.; Ruan, J.; Homer, N.; Marth, G.; Abecasis, G.; Durbin, R. 1000 Genome Project Data Processing Subgroup. The Sequence alignment/map (SAM) format and SAMtools. Bioinformatics 2009, 25, 2078-2079. [CrossRef] [PubMed]

53. Chavez, L.; Jozefczuk, J.; Grimm, C.; Dietrich, J.; Timmermann, B.; Lehrach, H.; Herwig, R.; Adjaye, J. Computational analysis of genome-wide DNA methylation during the differentiation of human embryonic stem cells along the endodermal lineage. Genome Res. 2010, 20, 1441-1450. [CrossRef] [PubMed]

54. Gruntman, E.; Qi, Y.; Slotkin, R.K.; Roeder, T.; Martienssen, R.A.; Sachidanandam, R. Kismeth: Analyzer of plant methylation states through bisulfite sequencing. BMC Bioinform. 2008, 11, 371. [CrossRef] [PubMed] 